\title{
The nutritive value of lupin seeds (L. luteus L. angustifolius and L. albus) for broiler chickens as affected by variety and enzyme supplementation
}

\section{Ourida Alloui, Stefania Smulikowska, Małgorzata Chibowska and Barbara Pastuszewska}

\begin{abstract}
The Kielanowski Institute of Animal Physiology and Nutrition. Polish Academy of Sciences 05-110 Jablonna, Poland
\end{abstract}

(Received 22 July 1994; accepted 14 Scptember 1994)

\begin{abstract}
The chemical composition and nutritional valuc of yellow (Juno and Popicl), bluc (Emir and Sur) and white (Wat and Bardo) Polish sweet lupin varieties were compared. The effects of enzyme preparations, Energex and Bio-Feed Plus, on the hydrolysis of the seed components in vitro and of Energex and Alpha-Gal on the nutritional value of lupin for broiler chickens, werc cvaluated.

The protein content was the highest in the yellow lupins $(44 \%)$, while that of fat in the white $(9 \%)$. The alkaloid content ranged from 0.23 to $1.3 \mathrm{~g} / \mathrm{kg}$ DM. The metabolizable energy (AME $\mathrm{N}_{\mathrm{N}}$ ) as determined on 4-wcek old chicks, was the highest in Bardo, the lowest in Emir (11.2 and $8.4 \mathrm{MJ} / \mathrm{kg}$ DM, respectively).

The apparent protein and fat digestibility of lupins determined on 4-week old chicks did not differ among cultivars and averaged 84 and $73 \%$, respectively. Relatively large differences in digestibility of carbohydrate fractions were noted among cultivars (c.g. NFE from 0 to $23.9 \%$; CF from 0 to $20 \%$ ).

The growth performance of broiler chicks fed between day 8-29 of life on isoprotein and isocaloric diets containing 15 and $30 \%$ lupin was determined. At the $15 \%$ inclusion level only Wat significantly lowered performance indices, however, at the $30 \%$ level these indices decreased significantly for all cultivars except Bardo.

In vitro, Energex increased the degree of hydrolysis of NDF and ADF in Wat by 19 and $10 \%$, respectively, and increased the solubility of protein of all lupin cultivars by $12 \%$, on average. In vitro Energex increased the $\mathrm{AME}_{\mathrm{N}}$ value of Juno. Emir, Sur and Wat by about $1.5 \mathrm{MJ} / \mathrm{kg} \mathrm{DM}$ and Alpha-Gal acted only on blue lupins ( $1.6 \mathrm{MJ} / \mathrm{kg} \mathrm{DM}$ ). However, supplementation of diets containing $23 \%$ of Juno and Emir seeds with $0.1 \%$ of Energex or Alpha-Gal did not improve the performance of the birds in a 3-week experiment.
\end{abstract}

KEY WORDS: L. luteus, I. angustifolius, L. albus, feed enzymes, digestibility, metabolizable cncrgy, broiler chicks 


\section{INTRODUCTION}

Three species of sweet lupin are grown in Poland: L. luteus, L. angustifolius and $L$. albus. As a result of genetic selection in each species, a number of low alkaloid varieties have been oblained. It has been assumed that due to their high protein content, lupins may substitute soyabean meal in poultry diets. The data concerning the feeding value of the new Polish lupin cultivars for broiler chicken are limited and opinions about their use varied. It has been concluded that the level of inclusion of lupin into broiler diets should be limited to $13 \%$ (Koreleski et al., 1987) or that it can successfully substitute all soyabean meal in the ration (Piech-Schleicher and Jamroz, 1982).

The nutritive value of lupin seeds for poultry depends mainly on their protein and amino acid contents and availability but also on their metabolizable energy, which is positively correlated with fat content and negatively with the indigestible fraction of non-starch polysaccharides (NSP). Metabolizable energy of lupins for poultry is low and varics from 8.2 (narrow-leaved) and 9.5 (yellow) to 10.7 (white) MJ/kg DM, according to Nutrient Requirements of Poultry (1993).

The above is a consequence of a high content of NSP, reaching $37 \%$ of lupin dry matter (DM). The main components of lupin NSP are oligosaccharides (Trugo and Almeida, 1988), pectins and hemicelluloses (Brillouet, 1984). None of these substances are digested or are digested only to a small extent by chickens, because the birds do not have an appropriate digestive enzyme system.

The use of enzymes such as hemicellulase, pectinase, $\beta$-glucanase and $\alpha$-galactosidase for degrading the main lupin NSP components may improve digestibility of nutrients and increase the energy value of lupin. The positive effect of galactosidase on the ilcal digestibility of lupin oligosaccharides, but not amino acids, was observed by Gdala et al.(1994).

Supplementation of poultry diets with commercial preparations containing enzymes degrading cereal NSP is now commonly used as an efficient means of increasing the energy valuc of cereal grain for poultry. It therefore seems possible that a similar procedure may be proposed to improve the utilization of lupin by chicken.

The objective of this study was to determine the nutritive value and metabolizable energy $\left(\mathrm{AME}_{\mathrm{i}}\right)$ of the six new varieties of sweet lupin for broiler chicken and to examine whether added feed enzymes would affect the hydrolysis of lupin seeds in vitro and in tests with chickens.

\section{MATERIAL AND METHODS}

Seeds of three lupin species grown in Poland, each represented by two varieties: L. luteus (cv. Juno and Popiel), L. angustifolius (cv. Emir and Sur) and L. albus (cv. Wat and Bardo) were used. 
Chemical composition of lupin seeds was estimated by conventional methods, NDF, ADF and ADL contents were determined according to Van Soest (1967) on a Fibertec $\mathrm{M}$ (Tecator) apparatus, total alkaloid content according to Wysocka et al. (1989). The amino acid content was determined on a Beckman amino acid analyser. Methionine and cystine were assayed after oxidation with performic acid, tryptophan after hydrolysis with barium hydroxide.

Feed enzymes produced by Novo-Nordisk: Energex ( $\beta$-glucanase, hemicellulase, pectinase, endoglucanase), Bio-Feed Plus (hemicellulase, $\beta$-glucanase, pentosanase) and Alpha-Gal ( $\alpha$-galactosidase, invertase) were used.

\section{Tests in vitro}

Samples of lupin seeds were finely ground on a Cyclotec 1090 Sample Mill (Tecator). Ten grams of each sample with or without $1 \%$ Energex or Bio-Feed Plus preparations were mixed in a $1: 10$ proportion with $0.1 \mathrm{M}$ sodium acetate buffer $(\mathrm{pH} 5.2)$ and incubated at $39^{\circ} \mathrm{C}$ for 5 or $10 \mathrm{~h}$. The mixtures were centrifuged and the nitrogen content in supernatants was determined. The samples were incubated in duplicate.

In the second test, after $10 \mathrm{~h}$ incubation with or without $1 \%$ Energex as above, the samples were freeze dried and analysed for NDF and ADF content according to Van Soest (1967).

\section{Experiments on chickens}

Experiment 1. Metabolizable energy value $\left(\mathrm{AME}_{\mathrm{N}}\right)$ of lupins was evaluated on 4-week-old cockerels with an initial body weight of $950 \mathrm{~g}$, divided into groups of nine birds each. The chickens were fed cold pelleted diets containing $100 \%$ of basal diet or $50 \%$ of basal diet and $50 \%$ of ground lupin seeds combined on a DM basis. All diets were fed non supplemented or supplemented with $0.3 \%$ of Energex or Alpha-Gal preparations. The composition of the basal diet is shown in Table 4, experimental procedures were according to Smulikowska and Chibowska (1993). $\mathrm{AME}_{\mathrm{N}}$ of lupins was calculated according to Campbell et al. (1983).

Experiment 2. The nutritional value of lupins was evaluated in a three-week experiment performed on eight-day old broiler cockerels (Vedetta) with an average initial weight of $133 \pm 5 \mathrm{~g}$. The birds were housed in pairs, 14 pairs per group, in cages equipped with a feed and water supply.

The cockerels were fed to appetite diets containing 0 (control), 15 or $30 \%$ ground lupin seeds of each evaluated cultivar. The composition of the diets is given in Table 7. Each diet contained: $20 \%$ crude protein, $11.7 \mathrm{MJ} / \mathrm{kg} \mathrm{AME}$, $1.06 \%$ lysine, $0.76 \%$ methionine + cystine, $0.76 \%$ threonine. All diets were cold pelleted. 
Experiment 3. Due to limited supply of lupin samples the effect of Energex and Alpha-Gal preparations on cvs. Juno and Emir only was estimated. The experiment was performed as Experiment 2 except that the initial average weight of the cockerels was $110 \pm 5 \mathrm{~g}$. The composition of the diets was similar as in Experiment 2 (see Table 7), but they contained only $23 \%$ of lupin seeds. The diets were fed unsupplemented or supplemented with $0.1 \%$ of Energex or Alpha-Gal preparations, as recommended by the producer.

Statistical analysis of the results was performed using "Statgraphics Plus ver.7" software.

\section{RESULTS}

The crude protein content was highest in yellow, lower in blue and white lupin; the fat content was highest in white lupin. The content of fibre was high in all cultivars, but intervarietal differences were found within species (Tablc 1). There were no distinctive differences in the amino acid composition of protein, however yellow lupins contained less threonine and tryptophan, the content of tryptophan was also very low in Wat. The content of alkaloids ranged from 0.23 to $1.3 \mathrm{~g} / \mathrm{kg}$ (Table 1).

TABLE 1

Chemical composition of lupin sceds. \% of D.M

\begin{tabular}{lrrrrrr}
\hline \multirow{2}{*}{ Species } & \multicolumn{2}{c}{ L. lutess } & \multicolumn{2}{c}{ L. angusifolius } & \multicolumn{2}{c}{ L. alhus } \\
& Juno & Popicl & Emir & \multicolumn{1}{c}{ Sur } & Wat & Bardo \\
\hline Crude protein $(\mathrm{N} \times 6.25)$ & 44.1 & 44.2 & 33.7 & 34.6 & 32.1 & 35.9 \\
Crude fat & 5.2 & 5.3 & 6.5 & 6.0 & 9.5 & 8.4 \\
Crude ash & 5.2 & 5.1 & 4.2 & 4.0 & 4.3 & 4.3 \\
Crude fibre & 14.3 & 13.5 & 12.7 & 16.5 & 15.4 & 15.5 \\
NDF & 23.4 & 21.6 & 21.3 & 26.5 & 23.6 & 25.1 \\
ADF & 19.4 & 18.4 & 17.9 & 23.5 & 19.9 & 23.3 \\
ADI. & 4.9 & 1.6 & 2.0 & 3.5 & 4.5 & 2.7 \\
Amino acids, g/6 g N & & & & & & \\
Lys & 5.10 & 5.02 & 5.05 & 5.00 & 5.14 & 5.12 \\
Thr & 3.19 & 3.17 & 3.65 & 3.53 & 3.87 & 3.86 \\
Trp & 0.78 & 0.78 & 0.97 & 1.00 & 0.78 & 0.89 \\
Met & 0.80 & 0.79 & 0.84 & 0.83 & 0.89 & 0.91 \\
Cys & 2.11 & 2.07 & 1.70 & 1.60 & 1.75 & 1.49 \\
Total alkaloids, g/kg & 0.23 & 1.30 & 0.44 & 0.51 & 0.95 & 0.79 \\
\hline
\end{tabular}


Protein solubility after incubation of ground seeds without enzymes was rather uniform; on average, after $5 \mathrm{~h}, 25.7 \%$ of $\mathrm{N}$ was found in the supernatant; $27.2 \%$ after $10 \mathrm{~h}$. Because the Bio-Feed Plus preparation had a very small effect on the solubility of nitrogenous substances, the Alpha-Gal preparation was used in further work instead. After incubation for 5 or 10 h with Energex 34 and $40 \%$ more nitrogen, respectively, was found in the supernatant (Table 2).

The amounts of dietary fibre components estimated as NDF and ADF after the incubation in buffer for $10 \mathrm{~h}$, were generally lower (Table 3 ) than measured in non-incubated samples (Table 1); the greatest difference was found in Bardo, the smallest in Popiel. The effect of Energex on the hydrolysis of NDF and ADF was negligible in all lupin varieties except Wat, in which $19 \%$ more NDF and $9 \%$ more ADF was degraded after addition of Energex (Table 3).

The digestibility of protein determined on chickens in vivo (Table $5 \mathrm{a}$ and $\mathrm{b}$ ) averaged $84 \%$, and no distinctive differences were noted amongst cultivars. The average fat digestibility was $73.3 \%$, the differences amongst cultivars were more distinct and reached 20 percentage units ( 81.7 for Wat vs. $61.2 \%$ for Emir). The digestibility of NFE averaged $9.7 \%$ for all cultivars, but ranged from 0 (Popiel and Bardo) to $23.9 \%$ (Emir). The largest differences were noted for ADF, NDF and crude fibre digestibility. Supplementation with Energex resulted in an increase of apparent digestibility of all components determined in all evaluated lupin cultivars except for protein in Wat, but the range of improvement varied. The effect of supplementation with Alpha-Gal was smaller.

The $A M E_{N}$ value for chicken of both narrow-leaved lupins was lower than that of yellow and white ones (Table 6). The metabolizability of energy differed amongst species and was the lowest in both narrow-leaved cultivars, lower metabolizability of energy was found also in cv. Wat. Supplementation with Energex resulted in an increase of $\mathrm{AME}_{\mathrm{N}}$ and metabolizability of energy of Juno, Emir, Sur and Wat, but was not effective with Popiel and Bardo, while supplementation with Alpha-Gal resulted in an increase of $\mathrm{AME}_{\mathrm{N}}$ and metabolizability of energy only in Emir.

Chickens fed diets containing 15\% lupin seeds gained on average $6 \%$ less than those fed the wheat-soyabean meal diet, and only Wat lowered body weight gain by $13 \%(\mathrm{P}<0.05)$. The feed conversion ratio worsened by $3 \%$ on average (Table 8). Introducing 30\% Wat, Juno, Sur and Popiel lupins into the diet further lowered the performance indices of chickens, only Bardo and Emir did not have this effect.

Supplementation of the diets containing $23 \%$ Juno and Emir seeds with $0.1 \%$ Energex or Alpha-Gal did not improve the performance of the chickens (Table 9). 
TABLE 2

Solubility of nitrogenous compounds of lupin secds incubated without (control) or with enzyme preparations during 5 and $10 \mathrm{~h}$ ( $\mathrm{N}$ found in supernatant as percent of tota! $\mathrm{N}$ )

\begin{tabular}{lcccccc}
\hline \multirow{2}{*}{ Variety } & \multicolumn{3}{c}{5 hours } & \multicolumn{3}{c}{ 10 hours } \\
& control & B-FP & Energex & control & B-FP & Energex \\
\hline Juno & 24.2 & 25.5 & 32.0 & 25.8 & 28.1 & 37.2 \\
Popiel & 24.7 & 25.5 & 32.6 & 24.4 & 27.9 & 36.8 \\
Emir & 26.2 & 27.7 & 32.0 & 29.1 & 32.5 & 42.3 \\
Sur & 25.6 & 26.0 & 37.2 & 27.8 & 28.5 & 41.5 \\
Wat & 25.5 & 28.2 & 35.4 & 26.2 & 30.2 & 38.2 \\
Bardo & 28.1 & 30.1 & 33.8 & 30.2 & 34.1 & 41.4 \\
Average & 25.7 & 27.2 & 33.8 & 27.2 & 30.2 & 39.6 \\
\hline
\end{tabular}

B-FP $=$ Bio-Feed Plus

TABI.T: 3

NDF and $\triangle D F$ remained in lupin seeds after incubation in vitro for $10 \mathrm{~h}$, without (control) or with Energex

\begin{tabular}{lcccc}
\hline \multirow{2}{*}{ Variely } & \multicolumn{2}{c}{ NDF } & \multicolumn{2}{c}{ ADF } \\
& control & Encrgex & control & Energex \\
\hline Juno & 21.3 & 20.3 & 17.7 & 17.7 \\
Popiel & 21.4 & 20.4 & 17.6 & 18.5 \\
Emir & 18.2 & 17.2 & 15.6 & 15.3 \\
Sur & 23.7 & 23.1 & 20.3 & 19.4 \\
Wat & 22.1 & 17.9 & 18.8 & 17.1 \\
Bardo & 20.9 & 20.3 & 18.7 & 18.3 \\
\hline
\end{tabular}

Composition of basal diet (Experiment 1). \%

\begin{tabular}{ll}
\hline Ingredients & $\%$ \\
\hline Soyabcan meal & 30.0 \\
Wheal & 65.6 \\
Calcium carbonate & 1.4 \\
Dicalcium phosphate & 1.6 \\
$\mathrm{NaCl}$ & 0.4 \\
Vitamin-mineral premix* & 1.0 \\
\hline
\end{tabular}

* supplied per kilogram of diet: retinol 8000 IU: cholecalciferol $1200 \mathrm{IU}$; tocopherol $10 \mathrm{mg}$; phylloquinone $2 \mathrm{mg}$; riboflavin $4 \mathrm{mg}$; pyridoxine $0.4 \mathrm{mg}$; cyanocobalamine $15.0 \mu \mathrm{g}$; niacin $12 \mathrm{mg}$; pantothenic acid $8 \mathrm{mg}$; folic acid $0.2 \mathrm{mg}$ : choline $150 \mathrm{mg}$; D-L methionine $1 \mathrm{~g}$; $\mathrm{Mn} 50 \mathrm{mg}$; Zn $30 \mathrm{mg}$; Se $0.1 \mathrm{mg}$; Co $400 \mu \mathrm{g}$; J $0.3 \mathrm{mg}$; BHT $100 \mathrm{mg}$ 


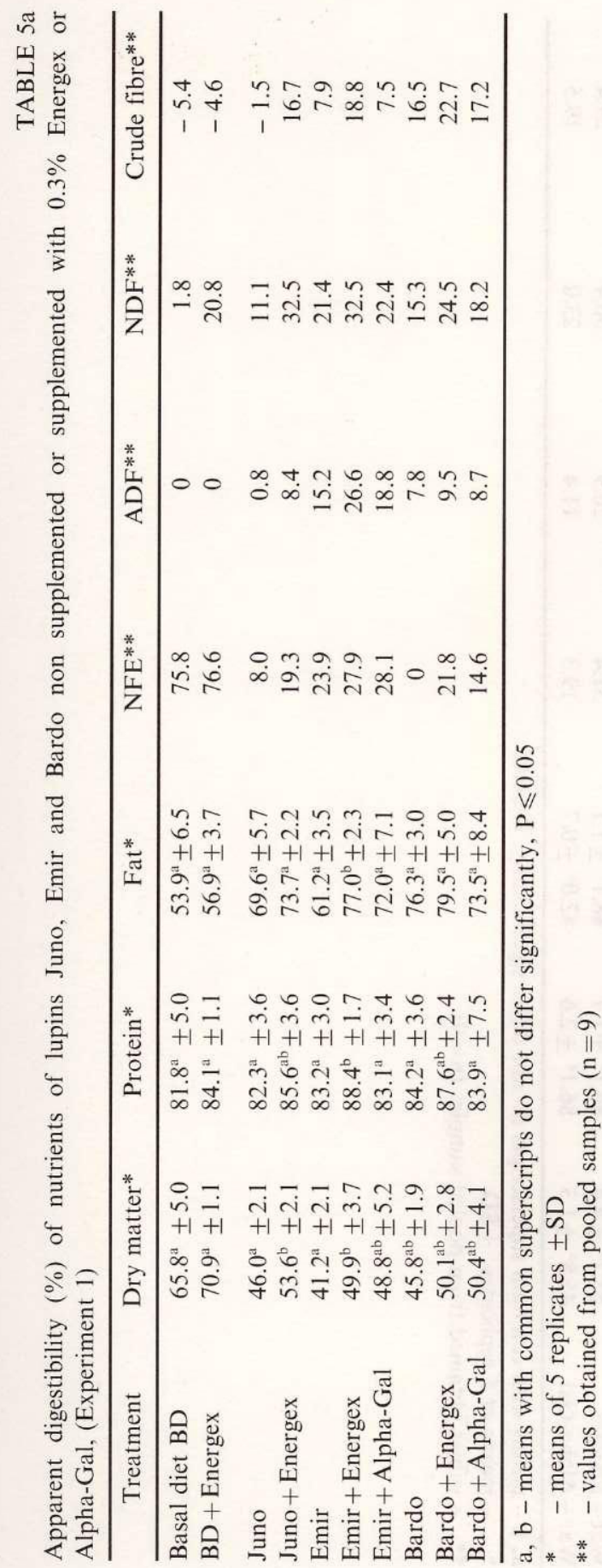




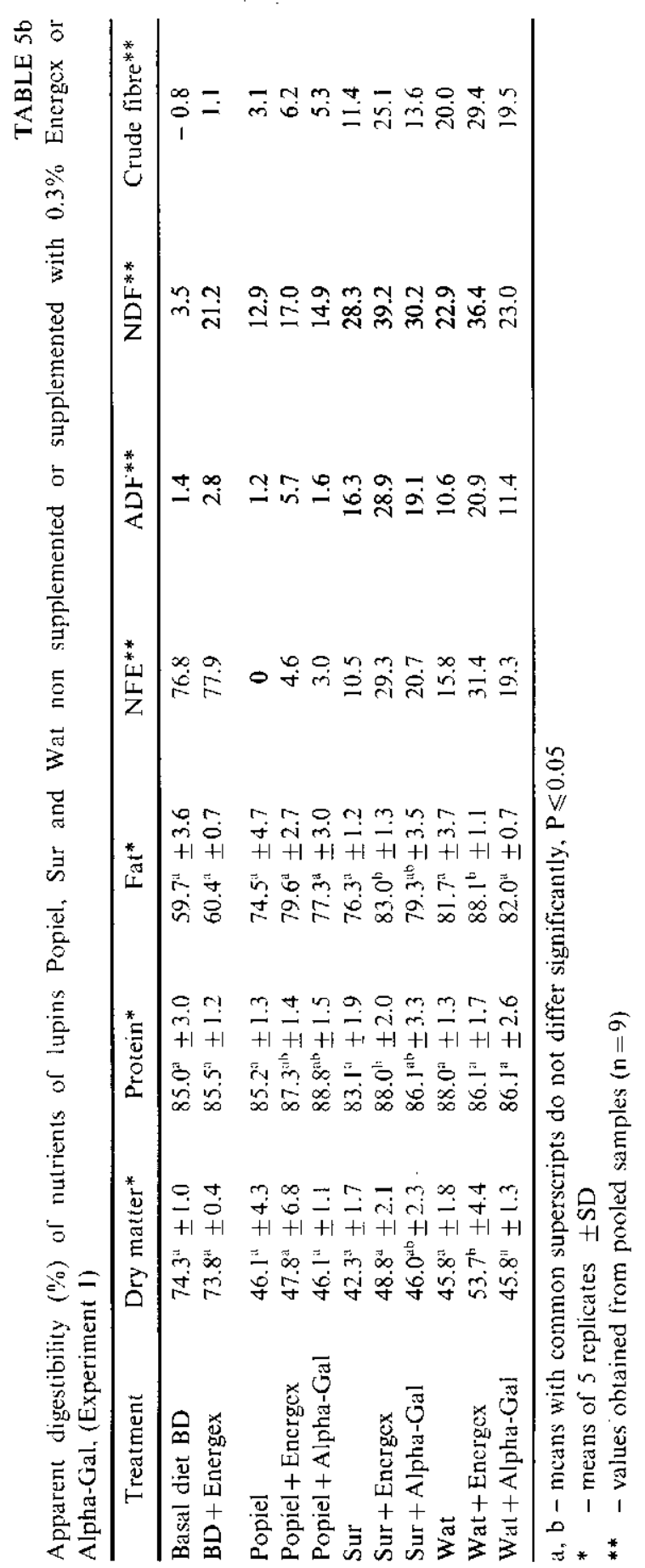


TABLE 6

Apparent metabolizable energy $\left(\mathrm{AME}_{\mathrm{N}}\right)$ and metabolizability of energy $\left(\mathrm{AME}_{\mathrm{N}} / \mathrm{GE}\right)$ of lupins without (control) or with Energex and Alpha-Gal (Experiment 1)

\begin{tabular}{lcccccc}
\hline \multirow{2}{*}{ Treatment } & \multicolumn{2}{c}{ L. luteus } & \multicolumn{2}{c}{ L. angustifolius } & \multicolumn{2}{c}{ L. albus } \\
& Juno & Popiel & Emir & Sur & Wat & Bardo \\
\hline AME $_{\mathrm{N}}, \mathrm{MJ} / \mathrm{kg} \mathrm{DM}$ & & & & & & \\
Control & $10.4^{\mathrm{a}}$ & $10.7^{\mathrm{a}}$ & $8.4^{\mathrm{a}}$ & $8.8^{\mathrm{a}}$ & $9.7^{\mathrm{a}}$ & $11.2^{\mathrm{a}}$ \\
Energex & $11.8^{\mathrm{b}}$ & $10.9^{\mathrm{a}}$ & $10.0^{\mathrm{b}}$ & $9.9^{\mathrm{b}}$ & $11.2^{\mathrm{b}}$ & $11.5^{\mathrm{a}}$ \\
Alpha-Gal & - & $10.8^{\mathrm{a}}$ & $9.9^{\mathrm{b}}$ & $9.2^{\mathrm{ab}}$ & $9.6^{\mathrm{a}}$ & $11.7^{\mathrm{a}}$ \\
SEM & 0.17 & 0.32 & 0.41 & 0.48 & 0.21 & 0.35 \\
\hline AME $/$ GE, \% & & & & & & \\
Control & $50.4^{\mathrm{a}}$ & $51.1^{\mathrm{a}}$ & $42.1^{\mathrm{a}}$ & $44.0^{\mathrm{a}}$ & $47.2^{\mathrm{a}}$ & $53.6^{\mathrm{a}}$ \\
Energex & $57.2^{\mathrm{b}}$ & $52.0^{\mathrm{a}}$ & $50.2^{\mathrm{b}}$ & $50.6^{\mathrm{b}}$ & $54.4^{\mathrm{b}}$ & $55.0^{\mathrm{a}}$ \\
Alpha-Gal & - & $51.4^{\mathrm{a}}$ & $49.8^{\mathrm{b}}$ & $46.2^{\mathrm{ab}}$ & $46.6^{\mathrm{a}}$ & $55.8^{\mathrm{a}}$ \\
SEM & 0.82 & 1.51 & 2.04 & 2.20 & 1.12 & 1.66 \\
\hline
\end{tabular}

$\mathrm{a}, \mathrm{b}$-means concerning the same cultivar were compared. Values with no common superscripts differ significantly $\mathrm{P} \leqslant 0.05$

TABLE 7

Composition of diets, \% (Experiment 2)

\begin{tabular}{lcccccccc}
\hline & $\begin{array}{c}\text { Lupin } \\
\text { seeds }\end{array}$ & Wheat & \multicolumn{1}{l}{$\mathrm{SBM}^{2}$} & $\mathrm{Fat}^{3}$ & $\mathrm{MVC}^{4}$ & Lys $^{5}$ & $\mathrm{Met}^{5}$ & $\mathrm{Thr}^{5}$ \\
\hline Serie 1 & & & & & & & & \\
Control & - & 59.71 & 32.0 & 4.0 & 3.9 & 0.16 & 0.09 & 0.14 \\
Popiel & 15.0 & 58.12 & 18.5 & 4.1 & 3.9 & 0.17 & 0.07 & 0.14 \\
& 30.0 & 56.62 & 5.0 & 4.1 & 3.9 & 0.18 & 0.05 & 0.15 \\
Sur & 15.0 & 52.62 & 22.7 & 5.4 & 3.9 & 0.16 & 0.10 & 0.12 \\
& 30.0 & 45.43 & 13.4 & 6.9 & 3.9 & 0.15 & 0.11 & 0.11 \\
Bardo & 15.0 & 54.04 & 21.9 & 4.8 & 3.9 & 0.15 & 0.10 & 0.11 \\
Serie 2 & 30.0 & 48.46 & 11.8 & 5.5 & 3.9 & 0.15 & 0.12 & 0.07 \\
Control & - & 62.39 & 29.0 & 4.3 & 3.9 & 0.19 & 0.08 & 0.14 \\
Juno & 15.0 & 60.49 & 15.8 & 4.4 & 3.9 & 0.21 & 0.05 & 0.15 \\
& 30.0 & 58.69 & 2.4 & 4.6 & 3.9 & 0.23 & 0.02 & 0.16 \\
Emir & 15.0 & 54.99 & 19.9 & 5.8 & 3.9 & 0.21 & 0.08 & 0.12 \\
& 30.0 & 46.97 & 11.2 & 7.5 & 3.9 & 0.24 & 0.09 & 0.10 \\
Wat & 15.0 & 54.30 & 21.0 & 5.5 & 3.9 & 0.12 & 0.08 & 0.09 \\
& 30.0 & 46.71 & 12.4 & 6.8 & 3.9 & 0.06 & 0.09 & 0.04 \\
\hline
\end{tabular}

in serie 1 wheat containing 10.87 , in serie $2-12.43 \%$ crude protein

${ }^{2}$ soyabean meal $-42.12 \%$ crude protein

${ }^{3}$ beef tallow + soyabean oil as $1: 1$

${ }^{4}$ containing in \%: limestone 1.2 ; dicalcium phosphate $1.4 ; \mathrm{NaCl} 0.3$; vitamin-mineral premix (as in exp. 1) 1.0

5 added to the diets 
TABLE 8

Performance of broiler chickens (7-28 days) fed on diets containing 15 or $30 \%$ of lupin (Experiment 2)

\begin{tabular}{|c|c|c|c|c|}
\hline Variety & $\%$ in diet & $\begin{array}{c}\text { Feed intake } \\
\text { (g) }\end{array}$ & $\begin{array}{l}\text { Weight gain } \\
\text { (g) }\end{array}$ & $\begin{array}{c}\text { Feed to gain ratio } \\
(\mathrm{g} / \mathrm{g})\end{array}$ \\
\hline \multicolumn{5}{|l|}{ Serie 1} \\
\hline Control & & $1625^{\circ} \pm 65$ & $931^{\mathrm{c}} \pm 55$ & $1.75^{51} \pm 0.08$ \\
\hline \multirow[t]{2}{*}{ Popicl } & 15 & $1582^{\mathrm{a}} \pm 99$ & $886^{1 x} \pm 72$ & $1.80^{\mathrm{ab}} \pm 0.08$ \\
\hline & 30 & $1570^{4} \pm 87$ & $830^{15} \pm 65$ & $1.89^{\mathrm{c}} \pm 0.07$ \\
\hline \multirow[t]{2}{*}{ Sur } & 15 & $1597^{a} \pm 120$ & $888^{\mathrm{bc}} \pm 69$ & $1.80^{\mathrm{ab}} \pm 0.10$ \\
\hline & 30 & $1522^{\mathrm{a}} \pm 170$ & $794^{4} \pm 97$ & $1.92^{\circ} \pm 0.08$ \\
\hline \multirow[t]{2}{*}{ Bardo } & 15 & $1591^{a} \pm 134$ & $863^{\text {ahx }} \pm 96$ & $1.85^{\mathrm{bc}} \pm 0.11$ \\
\hline & 30 & $1532^{i} \pm 145$ & $862^{a b c} \pm 93$ & $1.90^{\circ} \pm 0.08$ \\
\hline \multicolumn{5}{|l|}{ Serie 2} \\
\hline Control & & $1564^{\mathrm{b}} \pm 113$ & $859^{d} \pm 44$ & $1.82^{\mathrm{ib}} \pm 0.10$ \\
\hline \multirow[t]{2}{*}{ Juno } & 15 & $1450^{\mathrm{ab}} \pm 173$ & $811^{\mathrm{dd}} \pm 103$ & $1.79^{: 1} \pm 0.10$ \\
\hline & 30 & $1350^{\mathrm{a}} \pm 162$ & $716^{\text {ab }} \pm 86$ & $1.89^{: 1 x} \pm 0.08$ \\
\hline \multirow[t]{2}{*}{ Emir } & 15 & $1563^{b} \pm 117$ & $803^{\mathrm{cd}} \pm 81$ & $1.95^{c} \pm 0.09$ \\
\hline & 30 & $1432^{\mathrm{ab}} \pm 148$ & $795^{\text {bed }} \pm 74$ & $1.80^{\mathrm{a}} \pm 0.10$ \\
\hline \multirow[t]{2}{*}{ Wat } & 15 & $1438^{\mathrm{tb}} \pm 129$ & $749^{\text {the }} \pm 71$ & $1.93^{\mathrm{bc}} \pm 0.12$ \\
\hline & 30 & $1308^{a} \pm 81$ & $678^{\circ} \pm 61$ & $1.93^{\mathrm{bc}} \pm 0.08$ \\
\hline
\end{tabular}

a, b-means within the same serie were compared. Values in the columns with the same superceripts do not differ significantly, $P \leqslant 0.05$

TABLE 9

Performance of broiler chickens (7-21 days) fed on diets containing $23 \%$ lupin, non-supplemented or supplemented with $0.1 \%$ Energex or Alpha-Gal (Experiment 3)

\begin{tabular}{lccc}
\hline Treatment & Feed intake & Weight gain & Feed to gain ratio \\
& $(\mathrm{g})$ & $(\mathrm{g})$ & $(\mathrm{g})$ \\
\hline Juno & $1539^{\mathrm{a}}$ & $739^{\mathrm{a}}$ & $2.09^{\mathrm{a}}$ \\
Juno+ Energex & $1527^{\mathrm{a}}$ & $739^{\mathrm{a}}$ & $2.06^{\mathrm{a}}$ \\
Emir & $1516^{\mathrm{a}}$ & $691^{\mathrm{a}}$ & $2.20^{\mathrm{a}}$ \\
Emir + Energex & $1534^{\mathrm{a}}$ & $699^{\mathrm{a}}$ & $2.19^{\mathrm{a}}$ \\
Emir + Alpha-Gal & $1566^{\mathrm{a}}$ & $692^{\mathrm{a}}$ & $2.26^{\mathrm{a}}$ \\
SEM & 32.8 & 18.1 & 0.026 \\
\hline
\end{tabular}

a, $b-$ means with common superscripts do not differ significantly, $P \leqslant 0.05$ 


\section{DISCLSSION}

Comparison with the data compiled in the EAAT (European Amino Acid Table, 1992) shows that only yellow lupins fall within the European standard, both blue and white Polish sweet lupin species had lower protein and higher fat contents. The amino acid composition, expressed in $\mathrm{g} / \mathrm{l} 6 \mathrm{~g} \mathrm{~N}$, did not differ much amongst species and cultivars, and was in agreement with that given in EAAT (1992), so the procedure of calculating the amino acid composition of lupin, on the basis of its protein content seems to be justified. In comparison with soyabean protein, containing according to EAAT (1992) 6.2 g lysine and $1.37 \mathrm{~g}$ tryptophan per $16 \mathrm{~g} \mathrm{~N}$, lupin protein contained less lysine (5.07 $\mathrm{g}$ on average) and less tryptophan $(0.78-1 \mathrm{~g} / 16 \mathrm{~g} \mathrm{~N})$. The low content of both amino acids, but especially tryptophan, should be taken into consideration when soyabean meal is substituted by lupin, as synthetic tryptophan is not easily available.

The apparent digestibility of protein determined in vivo on chickens (Table 5) averaged $84 \%$, and no distinct differences amongst cultivars were noted. This value was however much lower than $92 \%$ given for all lupin species in the European Table of Energy Value for Poultry Feedstuffs (1989); the average apparent digestibility of fat was also lower (73.3 vs. 85\%). The differences among cultivars in fat digestibility were more distinct and reached 20 percentage units.

Relatively big differences were noted for NDF, ADF and crude fibre digestibility (Tables 5a, b). It seems, however, that the substances which formed these dictary fibre fractions were not fully digested, as both blue lupin species, which showed relatively high NDF and ADF digestibility, had the lowest $\triangle M_{N}$ values (Table 6).

The total alkaloid content varied from 0.023 to $0.13 \%$ DM, which do not exceed the limits for sweet lupin cultivars. However, even the highest alkaloid content, which in Experiment 1 in the diet containing $50 \%$ of Popiel seeds reached $650 \mathrm{mg} / \mathrm{kg}$, did not adversely affect feed intake.

It seems that the decrease in performance indices found on lupin diets in Experiment 2, was not caused by alkaloid content, but rather by lower than expected digestibility of lupin seed protein and fat. Due to this, the lupin diets delivered less amino acids and energy in available form than the control diet.

The results of the in vitro test indicate that in spite of the low effectiveness of Energex on the degradation of cell-wall constituents, NDF and ADF, this preparation, which did not contain protein degrading enzymes, increased the solubility of nitrogenous compounds of seeds. That may indicate that the activity of Energex is connected more with the soluble than the insoluble fraction of NSP. In contrast with Energex, Bio-Feed Plus had a small effect on protein solubility, the difference between the activity of two enzymes may be ascribed to the pectinase content in Energex. 
Energex was also effective in increasing the metabolizable energy value of some, but not all lupin cultivars. The response of different lupin cultivars to treatment with enzymes was not uniform, protein solubility increased after incubation with Energex in all lupin seeds evaluated, while significant $(P \leqslant 0.05)$ improvement of the $\mathrm{AMF}_{\mathrm{N}}$ value was found only for four varieties (Juno, Emir, Sur and Bardo). The lack of effect of Energex on $\mathrm{AME}_{\mathrm{N}}$ of Popiel and Bardo seeds as well as the positive effect of Alpha-Gal on $\Lambda \mathrm{ME}_{\mathrm{N}}$ of blue lupins only, cannot be related to the chemical composition of lupins as evaluated in the study. More detailed analysis is needed to explain the observed differences.

The very small effect of enzymes on the digestibility of protein and fat in white lupins is in agreement with the results of Brenes et al. (1993), who did not find any improvement due to supplementation of white lupin with Energex, Bio-Feed Plus or $\alpha$-galactosidase.

Generally, the results of the supplementation of lupin with feed enzymes do not secm to be very encouraging. The lack of a positive effect of enzymes on the growth performance of chickens fed on lupin diets may be explained by the nature of the sugars liberated by enzymes. Lupin NSP contain about $22 \%$ galactose, $11 \% \mathrm{D}$-xylose and 10\% arabinose (Carré and Brillouet, 1986), which are poorly utilized by chickens as energy sources (Longstaff et al., 1988; Shutte et al., 1990).

\section{REFERENCES}

Brenes A., Marquardt R.R., Guenter W., Rotter B.A., 1993. Effect of enzyme supplementation on the nutritional value of raw, autoclaved and dehulled lupins (Lupinus albus) in chicken diets. Poultry Sci. 72. 2281-2293

Brillouet J.M.. 1984. Carbohydrales of lupin seed. Proceedings 3rd International Lupin Congress, La Rochelie, France, 366-383

Campbell G.L, Campbell L.D., Blair R., 1983. Calculation of metabolizable energy for ingredienis incorporated at low levels into a reference diet. Poultry Sci. 62, 705-707

Carré B., Brillouet J. M., 1986. Yield and composition of cell-wall residues isolated from various feedstuffs used for non-ruminant animals. J. Sci. Food Agric. 37, 341-351

European Amino Acid Table. 1992. Publ. Group No 2, Nutrition. Furopean Federation WPSA, Beekbergen. The Neiberlands

European Table of Energy Value for Poultry Feedstuffs, 1989. Pub1. Group No 2, Nutrition. European Federation WPS $\Lambda$, Beekbergen, The Netherlands

Gdala J., Buraczewska L., Jansman A. M. J., Wasilewko J., van Leuwen P., 1994. Ileal digestibility of amino acids and carbohydrates in lupins for young pigs. VI International Symposium on Digestive Physiology in Pigs, 4-6 October 1994, Bad Doberan, Germany

Longstaff M. A., Knox A., Mc Nab J. M.. 1988. Digestibility of pentose and uronic acids and their effect on chick weight gain and caecal sire. Brit. Poultry Sci. 29, 379-393 
Korcleski J., Ryś R., Kubicz M., 1987. The seeds of new domestic varieties of lupin, pea and soya bean in feeding broiler chickens and rats (in Polish). Rocz. Nauk Zoot. Monogr. Rozpr. 25, 221-244

Nutrient Requirement of Poultry (in Polish). 2nd ed. 1993. Publ. of The Kielanowski Institute of Animal Physiology and Nutrition. Jabłonna, Poland

Piech-Schleicher A.. Jamroz D., 1982. The use of fodder yellow lupine seed in concentrated fecd mixtures for broiler chicken (in Polish). Zes\%. probl. Post. Nauk rol. 239, 57-65

Schutte J.B., 1991. Nutritional value and physiological effects of D-xylose and L-arabinose in poultry and pigs. Ph.D. Thesis, Wageningen Agricultural University, pp. 3-20

Smulikowska S., Chibowska M. 1993. The effect of variety, supplementation with tryptophan. dehulling and autoclaving on utilization of tield been (Vicia faba $\mathrm{L}$. ; seeds by broiler chickens. J. Anim. Feed Sci. 2, 181-188

Trugo L. C., Almeida D. C. F., Gross R., 1988. Oligosaccharide contents in the seeds of cultivar lupins. J. Sci. Food Agric. 45, 21-24

Van Soest P. J., 1967. Use of detergent in the analysis of fibrous feeds. IV. Determination of plant cell-wall constituents. J. Assoc. Off. Agric. Chem. 50, 50-55

Wysocka W., Brukwicki T., Jałoszyński R.. Hoffman K., 1989. A new and efficient method of extraction of alkaloids from lupin seeds. Lupin Letlers 13, 59-65

\section{STRESZCZENIE}

W pływ odmiany i dodatku enzymów na wartość odżywczą nasion lubinów (L. Luteus, L. angustifolius i L. albus) dla kurcząt brojlerów

Porównano skład chemiczny i wartość odżywczą polskich odmian łubinów: żółtych (Juno i Popiel), niebieskich (Emir i Sur) i białych (Wat i Bardo). 7.badano także wplyw preparatow enzymatycznych: Energex, Bio-Feed Plus i $\Lambda$ lpha-Gal na tempo trawienia składników nasion in ritro i ich wykorzystanie przez kurczęta.

Zawartość białka była najwiçksza w hubinach żółtych (44\%), thuszczu w białych $(9 \%)$. Zawartość alkaloidów wabala się od 0,23 do $1,3 \mathrm{~g} / \mathrm{kg} \mathrm{SM}$.

Wartość $\mathrm{AME}_{\mathrm{N}}$, oznaczona w doświadczeniu na 4-tygodniowych kurczętach, byla najwyżşa dla łubinu Bardo, najniższa dla łubinu Emir (odpowiednio 11,2 i 8,4 MJ $\mathrm{kg}$ SM).Pozorna strawność białka była podobna u wszystkich odmian i wynosiła śrcdnio $84 \%$, pozorna strawność tłuszczu $73 \%$. Stwierdzono natomiast düze różnice między odmianami w strawności frakcji węglowodanów.

Wszystkie łubiny włączono do izobiałkowych i izokalorycznych diet dla kurcząt brojlerów; podawano jc kurczętom miçdzy 8 a 29 dnicm życia. Przy udzialc $15 \%$ nasion w diecic jedynie Wat istomie obnizył przyrosty $\mathrm{i}$ wykorzystanie paszy, natomiast przy udziale $30 \%$ nasion $\mathrm{w}$ diecic wskażniki te obniżyły się istotnie dla wszystkich odmian 7. wyjątkiem Bardo.

W testach in vitro Energex spowodował zwiększenie rozkładu NDF i $A D F$ jedynie w nasionach odmiany Wat (o 19 i $10 \%$ ) oraz zwiçkszenic rozpuszczalności białka wszystkich odmian, średnio o około 12\%. In vivo Energex zwiçkszył wartość AME łubinów Juno, Emir, Sur i Wat o około 1.5 $\mathrm{MJ} / \mathrm{kg} \mathrm{SM}$, a Alpha-Gal jedynie obu odmian lubinu niebieskiego o $1,6 \mathrm{MJ} / \mathrm{kg} \mathrm{SM}$. Dodatek $0,1 \%$ obydwóch enzymów do diet zawierających $23 \%$ tubinów Juno i Emir nie wpłynął jednak na poprawę wzrostu i wykorzystania paszy przez kurczęta. 